\title{
Being fashionable yet modest: Negotiation and the politics of fashion among santriwati at pesantren
}

\author{
Fina Zahra \\ Media and Cultural Studies, Post Graduate Education, Universitas Gadjah Mada, , Jl. \\ Teknika Utara, Yogyakarta, Indonesia, 55284 \\ e-mail: fazha92@gmail.com
}

\begin{abstract}
Santriwati has been labelled as an old-fashioned people who study a more specific way of religion without knowing much about the social and reality in the society outside pesantren. Santriwati were also perceived to dress conservatively and old-fashioned. Different from that image, in one of female pesantren in Krapyak, Yogyakarta (here called $\mathrm{PiK}$ ), the santriwati dress themselves more fashionable. It might be because of the influence they attain from outside pesantren since they are allowed to study in college (formal education). In spite of the santriwati perceive that the fashion rules in PiK are moderate than other pesantrens they have known, there remain some who broke the rules while claiming that they are fashionable without exhibiting their body's shape. Those conflicting evidence I attempted to establish in this study. By doing so, I aim to establish how the santriwati of PiK constitute the meaning of themselves through negotiation in the fashion way. I find that santriwati do numbers of negotiation practices through the way they dress to actively conforming the rules. As for santriwati of the Security division, they have a privilege to suggest about certain dress based on the development in the society and fashions available in the market. Nevertheless, pengasuh's decision has the higher power and any changes in the rules must be a verdict from pengasuh called dawuh. Thus, it would be easier to reconcile when the santriwati complaint. Therefore, Security division utilizes pengasuh as a 'safeguard', regardless of the obedience.
\end{abstract}

\section{Keywords}

fashion, identity, negotiation, pesantren, politics of fashion, santriwati

Citation: Zahra, F. (2018). Being fashionable yet modest: Negotiation and the politics of fashion among santriwati at pesantren. In M. Amini, M. Yusuf, \& V. I. Yulianto. (Eds.), UGM Digital Press Social Sciences and Humanities: Vol. 1. Proceeding of the 2nd International Conference on South East Asia Studies, (pp. 27-32).

Published: October, 2018

\section{Introduction}

Santri is the name for students of Islamic boarding school (pesantren), while santriwati is a specific name for female santri. This research was started from my curiosity over the way santriwati in one of the female pesantrens in Krapyak, Yogyakarta (to be more simply called PiK), dress. Pesantren is an informal education institution in Indonesia, it has an image as a slum with its own regulations covering many aspects, ranging from activities that must be followed by the santriwati called pengajian (one of Islamic rituals by studying al-Quran and yellow Islamic books), fashion way, and various things oriented to the norm as a good follower of Islamic religion. By the view of pesantren, the 
purpose of education and various rules there is to construct santriwati who are religious, able to socialize well, as well as able to understand the problems in society. In order to achieve the goal of pesantren education, pesantren has been strictly limiting the space and practice of consumption of santriwati. Some pesantren even restrict the santriwatis by prohibiting to school outside the pesantren and providing school in pesantren only. Pesantren also restricts the goods carried by santriwatis, such as confining the model of clothes santriwati wear and electronics they use. Therefore, in the society, santriwati are often labelled as people who are not intellectuals, believe in mythic, conservative, old-fashioned, and outdated. Koentjaraningrat stated that santri termed with old-fashioned or conservative (Usman, 2009, p. 301).

Discussing santriwati's (female santri) fashion is an interesting thing because fashion itself is often associated with women. In addition, women's fashion is more varied than men's fashion. Thus, there might be many negotiation practices that can be extracted from the object. Previously, I assumed santriwati as old-fashioned people who studied in a more specific way of religion without knowing about the social and reality in society outside pesantren, and their clothing behaviour should be more modest than other students. However, it was not true at all when looking at the fashion of santriwati of PiK. Their fashion was not much different from other female students in Yogyakarta. Meanwhile, santriwati of PiK has been allowed to study in college outside pesantren. Hence, I consider the function of fashion by Craik that fashion is used to highlight relations between the body and its social habitus because the body is not a given, but actively constructed through how it is used and projected (Craik, 1993, p. 9).

This research uses a new ethnography method, which emphasizes the characteristics of shifting two logics between the researcher's and the subject's perspective. Doing new ethnography, the researcher does not claim to capture the people's view 'right' from the outside, but aims to be faithful to people's lived perspectives (Saukko, 2003, p. 57). As I had an entanglement with the object of the research for five years, I made an observation based on my experience as a santriwati in PiK who also became a member of Security Division for three years and a half; a year and half as a Coordinator. The most worrying thing is the dullness of my critical attitude to the object of the research of which subjects mostly are my friends and it may greatly affect my research. Hence, I anticipate my lack in critical attitude by learning from Shostak's personable reflection research titled Nisa in 1983 as Saukko wrote, the research was criticized because it was considered take the researcher's sentimental and omit the critical attitude (Saukko, 2003, p. 64). Therefore, I attempt to adjust self-reflexivity as a characteristic of new ethnography in this research. Selfreflexive characteristic in new ethnography were done in an effort to understand the object of research by staying critical. The data for this research was obtained from field observation and interview with the informer/resource person.

I conducted the research in 2015, a year after I graduated from PiK. But I did the observation and nonformal interviews while I was there. Most of the santriwati I met considered that PiK's regulation of clad barrier was considered quite moderate compared to other pesantren they once knew. They regarded to look fashionable but not too show their body curves that are considered violate the religious norms. Interestingly, although the rules of fashion in PiKare regarded moderate enough, when fashion raid is held, many clothes are founded considered to break these rules, such as semi-transparent or a cloth that was too short. Besides, it is often encountered santriwati who are admonished for breaking the boundaries of the rules since the cloth was too tight. Therefore, these facts raise a question about how and why the santriwati practice to negotiate with the rules of fashion in PiK.

It is the Security division who have a particular duty to conduct a raid once a year and admonish if there is a violation against the rules. The Security division within the PiK consists of several santriwatis who have a responsibility to socialize the boundaries of santriwati fashion and also to enforce the santriwati to always follow the rules, also they have the authority to confiscate the cloths against the rules there. Members of Security division were elected by the Daily Governing Committee (Badan Pengurus Harian/BPH) which were then submitted to the pengasuh for approval. In the context of pesantren, figures who maintain the whole system called Kiai and Bu Nyai, while their son is called Gus and their daughter is called Ning. They are admired and exemplified by the santriwati in many ways and commonly called pengasuh, such parents in pesantren. Related to this, the research also wanted to know whether in PiK Ning as female pengasuh became the main reference for santriwati's fashion.

I conducted an in-depth interview with an informant, she was currently a Coordinator of the Security division in PiK and it was known that before becoming a member of the security division, she broke the rules of fashion in PiK several times. In this report, I call her with initials: SA. She had completed her undergraduate education at State Islamic University in Yogyakarta. From the background of SA, I expected to explore more information about how the practice of dressing and its meaning for the santriwati, both from the point of view of santriwati who broke the rules of fashion and the security division that seek to reinforce existing regulations. 


\section{Findings and Discussions}

\subsection{Santriwati's Practices Toward Regulation of Fashion in PiK}

It has to be understood that each pesantren has its own vision and rules, it cannot be over-generalized. The regulation of santriwati fashion in PiK is claimed based on Ahlussunnah wal Jama'ah's teachings, and based on the polite and proper rules of Islam in the Nahdhatul Ulama' (NU) schools, which may vary (colour, style and model) but not tightly or transparent that can highlight body curves. When this research is done, in PiK there is no detailed regulation on the dress code of santriwati. Just mentioned, forbidden to wear clothing and transparent veils, tight shirts and shorts inside or outside the pesantren. Also forbidden to wear jeans, semi jeans, pencil, and too loose pants; because it does not look neat. Santriwati is allowed to wear colorful and various accessories but there was a limit on the number of clothing that might be taken in, which was 5 sets only. The reason was that each santriwati only permitted to use a cupboard from pesantren for all of their stuff and its size was small. However, the limit on the number of clothes is no longer emphasized because the santriwatis in PiK almost all of them also do activities outside pesantren, such as college, work, and follow organizations there, so that the clothing also more and varied.

It has been mentioned in the introduction that the santriwati in PiK had diverse fashion and tend to follow the trend. According to SA, santriwati of PiK have a fashion that is diverse and up to date influenced by their college environment. In fact, santriwati fashion who study in different faculties alone can have a different fashion. However, SA said that santriwati of PiK fashion are considered 'better' than other pesantren. SA said:

"I think the fashion of santriwati of PiK is not too out of the rules of the pesantren and is still reasonable to be used by santriwati. When compared to other pesantrens, their fashion is not too trendy, still considered more polite, and not excessive. For example, the santriwati here do not wear tight shirts like the one used by the santriwati in the next pesantren."

Despite being 'better' than other pesantren, it is also known that some santriwati still break the boundaries of fashion in PiK. Some santriwati wore forbidden clothes to go to campus or other activities outside pesantren such as hanging out. The most frequently encountered violations are clothes that are considered too short because the length does not cover the buttocks. In addition, the wrinkle fashion was also still widely used. Wrinkle clothes and long dress made by shirt material are prohibited because they are considered too tight and accentuated the curves of the body so it is not appropriate to be used by a santriwati. SA also said that actually there quite a lot of santriwati who wear fashionable dresses and break the rules, but they only wore it at certain times such as weddings. This is done in secret because there are feelings of anxiety if they meet a friend from pesantren at that time, especially from the security division. At this point, the rules and sanctions are enforced in order to discipline these norms into each santriwati. The rules then became a form of moral consciousness while creating a kind of panoptic fear. Panopticon is a metaphor for power mechanism in the work of Foucault for a continuous, anonymous and all-pervading power and surveillance operating at all levels of social organization (Barker, 2004, p. 162).

\footnotetext{
"The panopticon mechanism is not simply a hinge, a point of exchange between a mechanism of power and a function; it is a way of making power relations function in a function, and of making a function through these power relations" (Foucault, 1995, pp. 106-107).
}

Also as Mauss quoted (Craik, 1993, p.1):

"From a simple masquerade to the mask, from a 'role' (personnage) to a 'person' (personne), to a name, to an individual; from the latter to a being possessing metaphysical and moral value; from a moral consciousness to a scared being; from the latter to a fundamental form of thought and action-the course is complete".

The rules of fashion for santriwati of PiK are intended to be really absorbed by the individuals. However, the purpose of this discipline could not be true, since the santriwati could perform numbers of negotiation practices. In PiK, the Security Division is consisted of 6-10 members and deploy in 5 rayons. Meanwhile, the amount of all santriwati are about 300. So if it is required, the Security division reserve the right to elect a "spy" in secret from each room. The "spy" was asked to report the condition of her room. However, the duty as a "spy" is not considered mandatory as a task of a Security division and as such, the Security division seldom elects the "spy". Therefore, a chance to break the rules of fashion in PiK is actually wide, also because the santriwati are allowed to do activities outside pesantren. 
The santriwatis usually store the forbidden clothes in their relative house or their friend's boarding house and wear them there. But, some santriwati also dare to hide them in their cupboard in pesantren, because the clothes raid is only conducted once a year. Besides, the information of the raid which is conducted confidential among members of the security division and BPH was also known by some santriwati, so they are trying to hide their forbidden clothes in various places, such as: inside the pile of bags, inside the cardboard box above the cupboard, among piles of dirty clothes, or in motorbike baggage. Meanwhile, when wearing these clothes to the campus, for example, they would use a jacket to cover it. Also, since they could to rent a boarding house, they could save their forbidden clothes there.

Another thing that is also very important to be explored in this research is how the meaning of santriwati to fashion, both from the side of the santriwati who break the rules and from the security division side, since members of Security division are also santriwatis in PiK. Before SA became a member of the Security division, she already knew what kind of clothes are prohibited and why those are prohibited. However, she still wore it because she felt the need to adjust to the environment and her friends on campus. When the clothes were confiscated, SA felt she had enough. However, that did not mean that she would not wear them again. Especially when she is at home, SA often wear clothes that are prohibited by the rules of pesantren. According to SA, what she does is also affected by her family which have loose fashion rules. Her family do not make a fuss about wearing a shirt or jeans, except skinny jeans. SA's practices give an idea that one fashion could not be applied in all spaces. Each room seemed to demand a different fashion from others. Fashion is a technical tool that articulates the relationship between body and social environment; construct a personal habitus (Craik, 1993, p. 4).

In terms of fashion of santriwati of $\mathrm{PiK}$, it seems that space became something important. How the santriwati dress and negotiate in the pesantren and in the campus environment, and how they compare themselves to santriwati from other pesantren. Frisby and Featherstone (1997, p. 141) explained the importance of an awareness of the boundaries of space (consciousness of boundedness). This awareness makes space unconstrained by physical things such as mountains, seas, or pesantren walls, but rather by space in social interactions. Space boundaries do not actually have social consequences, but it is social facts that create spaces and their boundaries. This awareness is very political; not merely passively resistant, but actively resisting. This awareness then led to the negotiations made by the santriwati against the rules of clothes in pesantren.

The santriwati's negotiations are way to adapt to their environments, as Crawley (cited by Johnson, Torntore, and Eicher, 2003, p. 9) believes dress should be treated in the same way as weapons, machines, and tools, since dress is a means for extending the body's capabilities and for allowing social display. Those also done by SA, even after she became a member of the security division. She actually had broken the rules several times. But eventually, she no longer does it because she is increasingly aware that as a member of the security division, whatever she does would always highlight and excavated by others (other santriwatis). SA says:

"Before I became a member of the Security division, I did not break the rules much, even if they existed. After becoming a member of the Security division, I began to be careful not to violate, though yes still, ever several times. But after becoming a Coordinator now, I'm being very cautious, because I realized that the security division is most often highlighted. If you're not careful, it could be a boomerang".

SA told that as an ordinary santriwati before becoming a member of the security division, she once tried to wear the forbidden clothes in her room in pesantren. In order not to get caught, she closed the door and even the mosquito net. However, it actually raised suspicion and she was found out. This incident turned out to be raised again and disputed by the santriwati when she became a member of the security division. Santriwati who questioned it also made it an excuse to disobey the rules. It was then she thought her attitude could be a boomerang for herself, so she decided not to break the rules again since she not only has to take care of herself but also has to take care other santriwatis.

\subsection{Political Space and Self-Defense}

In the rules of dress in $\mathrm{PiK}$, regulatory changes often occurred. This is done by reason of adjusting the times and fashions exist. According to SA, it is difficult to only maintain conventional fashion such as baju kurung (enclosed dress), because the clothes on the market always changed. She then exemplified the regulatory changes in the case of jeans jackets. At first, a jacket made of jeans was not allowed, but then it is allowed except for a blue jeans jacket. The reason, jackets made of jeans are widely owned by santriwati and on the market that kind of jackets is a common fashion. They knew that kind of jacket was prohibited, but they still wear it stealthy. They also tried to negotiate by asking about this several times to the Security division 
and BPH. Then in a forum called forum santri, some santriwati spoke up about this matter. The forum was held once a year, specifically aimed at facilitating the communication of the board with santriwati. Then after discussed it for a while, jackets made of jeans are allowed to be used by santriwati except for the blue one. Blue jeans jacket remains prohibited because it was still seen as a dress that was identical with negative impressions such as rebellion and thuggery.

Changes in the rules are often initiated by the Security division, but it is sometimes pengasuh who called the Security division to discuss the regulatory changes. Any changes must be made or discussed in advance and must be approved by pengasuh. The Security Division did it by bringing in a few samples. Samples were obtained from the observation of trends in campus, online shop, and clothing that was circulated in the market. However, there were also differences of views between pengasuh and the Security division. If according to pengasuh a cloth was not appropriate but according to the Security division was still within reasonable limits, the pengasuh's opinion was won. This is because pengasuh as a respected figure and considered as a model.

The discussion between pengasuh and Security divisions is actually political since not all types of clothes were put forward for discussion. There is a gap where the Security division could make its own decisions, whether the clothes with a particular model, for example, might be used or not. This became a kind of looseness that also provoked protests. However, there are always implications for the actions of the Security division because it is in the middle, face to face with pengasuh and the santriwati. When there were santriwati who protest the rules, it would be long and difficult to explain if it was an independent act of the Security division. But if what is being protested had been approved by pengasuh, then the phrase "this is dawuh of pengasuh" to be a weapon. This means, regardless of the respect for pengasuh, the Security division often made pengasuh's rules and approval as a 'shield' in reducing santriwati's rejection.

In the way santriwati of PiK practice, fashion has double rules derived from the PiK with its old-fashioned and social environment in a more liberal campus. Arnold (2001, p.12) explained from Simmel's,

"Dress can be used as an indicator of group identity, including all those who adhere to particular tenets of taste and style,

but this necessarily excludes anyone who does not adopt the group's dress code".

Both campus and pesantren environment have their own demands and consequences, so the santriwati in PiK must adjust to the two parties, negotiate in order to get recognition from both parties. Based on the research, it could be concluded that fashion as a social circle on campus tends to be a reference. Meanwhile, fashion as arranged by the pesantren became a fashion that santriwati were trying to abandon. Santriwati of PiK acknowledged themselves as a santriwati with an old-fashioned background, but on the other hand, they are also hooked to keep up with the times. The santriwati's label as the old-fashioned might be unconsciously giving a negative impression they want to change. Responding to this, the santriwati try to change their fashion in order to get into the wider area in social interaction. Fashion as a user code used to present itself in front of others.

"Image is a picture that one wishes to project to win approval, respect or prestige by appearing stylish,

sophisticated or chic, and and it functions within an interpersonal network system" (Holbrook and Dixon cited by

Kawamura, 2005, p. 94).

In the case of the santriwati of PiK, both ordinary santriwati and the Security division are probably 'uncomfortable' with the old-fashioned labels, but they also consider that the rules adopted by the oldfashioned are the rules they should follow. Therefore, while trying to follow the trend of fashion, the santriwati still try not to violate the old-fashioned norms existed. This negotiation becomes an effort to conforming the rules. By doing so, the santriwati took an active action to choose and negotiate. As Giddens (2006, p. 99) stated,

"Bodily appearance concerns all those features of the surface of the body, including modes of dress and adornment,

which are visible to the individual and to other agents, and which are ordinarily used as clues to interpret actions".

Choosing to follow fashion in the market to build a distinction from the old-fashioned label yet remain obedient to the old-fashioned rules, the santriwati are trying to construct their own identity in front of others. They represent an ambivalence that Wilson called 'modernist irony', as cited by Craik (1993, p. 7):

"Fashion is a flexible means of expressing the ambiguity of capitalism, identity and art, thereby becoming 'modernist irony"'.

In PiK, there two Nings who are considered by the santriwati equally fashionable. Both looked fashionable but with a loose dress and did not show body curves. In addition, both are also career women besides being housewives with 3 children. Ning in PiK become a respected and admired figure. Some santriwati also praise Ning's fashion. But apparently, Ning figure do not have much effect on the fashion of the santriwati. According to SA, it is probably due to the status of the Ning who have 3 children, although 
they looked good Ning has different styles from santriwatis. From the results of the observations, for some santriwati, Ning's fashion is used as a benchmark on how Muslimah did fashion that looks attractive though loose. However, according to SA, Ning's fashion is more often used as a comparison, such as if the santriwati are not allowed to wear shirts gamis, santriwati protested because Ning also used it. When it was discussed again with Ning, there was a refutation from Ning in question that she was wearing a loose shirt, while santriwatis did not consider leeway and only paid attention to the model, so that the clothes worn look tight.

\section{Conclusions}

The santriwati of PiK treat fashion as a way to construct their own identity in front of others. It could be concluded that the "self-esteem" for santriwati of $\mathrm{PiK}$ is built from the accumulation of pesantren regulations, public opinion, and social circle on campus, while the self of santriwati owns a very little control. The santriwati of PiK consideration of themselves that they are dressed fashionable without overlay breaking the rules of pesantren become the proof.

In PiK, Ning has only a little effect on santriwati attitude in fashion. Ning is admired and viewed as a comparison. Once Ning was judged by santriwati as breaking the rules of fashion in PiK, santriwati protested, while Ning had a reason to dodge. Santriwati have no power over Ning and Ning set themselves what fashion they wear.

\section{References}

Arnold, R. (2001). Fashion, desire, and anxiety: Image and morality in the 20th century. London and New York: I.B. Tauris Publishers (p. 12).

Barker, C. (2004). The sage dictionary of cultural studies. London: Sage Publications Ltd. (p. 162).

Craik, J. (1993). The face of fashion. New York \& Canada: Routledge (pp. 1,4,7,9).

Foucault, M. (1995). Discipline and punish (Alan Sheridan, Trans.). New York: Random House, Inc. (pp. 106-107).

Frisby, D., \& Featherstone, M. (1997). Simmel on Culture. London: Sage Publication (p. 141).

Giddens, A. (2006). Modernity and self-identity. Cambridge: Polity Press (p. 99).

Johnson, K.K.P., Torntore, S.J., \& Eicher, J.B. (2003). Fashion foundations: Early writings on fashion and dress. Oxford and New York: Berg (p. 9).

Kawamura, Y. (2005). Fashion-ology: An introduction to fashion studies. Oxford and New York: Berg (p. 94).

Saukko, P. (2003). Doing research in cultural studies. London: Sage. Publication (pp. 57,64).

Usman. (2009). Tinjauan buku: Paradigma baru dalam kajian Islam Jawa. [Book review: New paradigm on Javanese Islam studies]. Jurnal Masyarakat dan Budaya, 11(2): 297-307. [In Bahasa Indonesia]. 